\title{
SLC26A3 wt Allele
}

National Cancer Institute

\section{Source}

National Cancer Institute. SLC26A3 wt Allele. NCI Thesaurus. Code C51091.

Human SLC26A3 wild-type allele is located within 7q31and is approximately $38 \mathrm{~kb}$ in length. This allele, which encodes chloride anion exchanger protein, plays a role in the mediation of electrolyte and fluid absorption. Defects in the SLC26A3 gene produce variant alleles that are the cause of congenital chloride diarrhea (CLD). 